\title{
Measuring Good Governance for Better Government
}

\author{
Lailul Mursyidah \\ Departemen Administrasi Publik \\ Universitas Muhammadiyah Sidoarjo \\ Sidoarjo, Indonesia \\ lailulmursyidah@umsida.ac.id
}

\author{
Totok Wahyu Abadi \\ Departemen Ilmu Komunikasi \\ Universitas Muhammadiyah Sidoarjo \\ Sidoarjo, Indonesia \\ totokwahyu@umsida.ac.id
}

\begin{abstract}
Good governance is the principle used in the management of government organizations as a way to improve the quality of development in the region. This research aims to analyze the index of good governance in Sidoarjo. This research is a descriptive-quantitative study that took 625 respondents who are residents of Sidoarjo as a sample. The data are collected through distributing questionnaires. The data collected is analyzed using good governance index analysis. The results showed that Good Governance Index of Sidoarjo in 2016 amounted to 65.35 , it means that the implementation of good governance in Sidoarjo is good. The highest good governance principle index is the rule of law principle amounted to 66.83, while the lowest good governance principle index is the responsiveness principle amounted to 62.91. Local government policy in providing legal certainty and guarantee to the community in various fields (eg. service) is the indicator with the highest index, whereas the community knowledge about the mechanism and procedure of complaint submission to the local government is the indicator with the lowest index.
\end{abstract}

Keywords-good governance index; local government

\section{INTRODUCTION}

Developing a bureaucracy that has the characteristics of good governance in the context of Indonesia is still far from expectations. The results of the 2012 Indonesia Governance Index [1] study showed that good governance index in Indonesia was 5.70. While the good governance index of East Java province was 6.43 [1]. These conditions indicate that there are still problems in the implementation of good governance. One of the causes is public dissatisfaction with health and education services as also public distrust about bureaucracy.

Good governance is not only related to government [2], but also involving stakeholders and the community. Governance quality, nation, and society with the pattern of synergy and constructiveness relationship and mutual interdependence in the life of society, nation and state to achieve the common goal of improving social welfare. These three things (state, private, and society) are one unity that can not stand alone. bureaucracy with good governance characteristics oriented towards effective and efficient public services and can be trusted by society [3], transparency, public participation, public health, social welfare, and the growth of conducive economic climate [4].

Good bureaucracy is a bureaucracy capable of maintaining and improving the productivity of performance to provide the best public service. The concrete and major steps needed are encouraging morale in the bureaucratic environment and increasing the capacity of bureaucrats to have adequate government management knowledge and reliable performance. Currently, bureaucracy has low capacity [5] and tends to be perceived in less good sense as it is identical with complicated procedurs, inefficient, slow, inhibiting, corrupt, and so forth [6] - [8]. The poorly perceived of bureaucratic structure and orientation is the implication of applying the principles of Max Weber's rational bureaucratic model.

Implementation of Local Autonomy assumed by various parties can bring a very significant change to the pattern of government management in the implementation of the main functions of government. These functions are development, service, and community empowerment. The shift of authority from the central to the local government has had an enormous impact in all aspects. The enactment of Law Number 23/2014 on Local Government [9] is expected to have a real impact on the improvement of public service.

To realize good governance as mandated by Law Number $23 / 2014$ [9], good governance needs to be measured in index form. Measuring the good governance index is important because it can be used as a measuring tool to determine the success of governance and sustainable development in a region. Theoretically, the approach of good governance refers to eight concepts, that are rule of law, participation, transparency, accountability, responsiveness, equity, effectiveness and efficiency, and strategic vision [10] - [12].

Based on the explanation, the problem in the research is: how far the implementation good governance in Sidoarjo? This paper aims to discuss the practice of governance in Sidoarjo based on the measurement of good governance index.

\section{METHODS}

This quantitative descriptive research was conducted through a survey of community perceptions living in Sidoarjo. The sample of this study were 625 respondents with $96 \%$ confidence level and $4 \%$ precision. Characteristics of 
respondents of this research are residents who live in Sidoarjo with a minimum of high school education and aged 19 until 60 years old. Respondents of this research are local government bureaucrats, board members, businessmen, judges and lawyers in Sidoarjo, lecturers, students, NGOs, editors or journalists, private sector employees, and community.

Data collection was done by distributing questionnaires to respondents. Questionnaires arranged using questions that refer to eight principles of good governance, which are rule of law, participation, transparency, accountability, responsiveness, equity, effectiveness and efficiency, and strategic vision. The answers to questions are arranged using the Likert scale. The data collected then coded, intervened, and tested the level of validity and reliability. Validity and reliability test results show that all items are valid with a score above 0.665 . While the reliability of the data shows a score above 0.910 which means very reliable.

Data analysis has done by finding index of each principle of good governance and the aggregate of good governance index. The index of each principle is obtained by dividing each variable per principle with an ideal score per principle and multiplied by one hundred percent. While the good governance index obtained by summing each principle and multiplied by the equal score is $1 / 8$. The results then consulted with Table 1.

TABLE I. THE CATEGORIES OF GOOD GOVERNANCE INDEX

\begin{tabular}{|c|c|}
\hline Good Governance Index & Category \\
\hline $0<=\mathrm{IGG}<=20$ & Very Bad \\
\hline $20<\mathrm{IGG}<=40$ & Bad \\
\hline $40<\mathrm{IGG}<=60$ & Fair \\
\hline $60<\mathrm{IGG}<=80$ & Good \\
\hline $80<\mathrm{IGG}<=100$ & Very Good \\
\hline
\end{tabular}

\section{RESULTS}

Good governance is the implementation of governance based on the synergistic relationship of the three pillars that are state, private, and society. The implementation of quality government can be measured in eight dimensions. First, rule of law is the practice of governance based on the rule of law applicable in any decision-making, clean of corruption, collusion and nepotism, the minimization of human rights violations, and the just law enforcement of a person or group in committing an offense. The quality of law enforcement in the regions can be observed from the availability of legal bases such as local regulations and the head of local government decisions related to their authority, communitybased policies, policies that provide certainty and legal guarantees, and the conformity of local regulations with the regulations above it. Law enforcement in its implementation can be done by local governments through good public order and security, reduction, enforcement of local regulations offense, and consistency to obey the regulations. Table 2 shows the results of measuring the principles of legal obedience in governance. Legal obedience shows an index of 66.83 which means that the implementation is good.

Participation is the second dimension used to measure good governance. Participation is the involvement of community members in policy making. The involvement is frequency in the process of policy formulation and monitoring of government practice. The intensity of community involvement in policy formulation may include the preparation and local policies making, knowledge of the mechanisms of participation in the formulation of policies, and the use of media or forums to participate. Most importantly, participation is the accommodating of inputs from the community by the local government. Community involvement in the implementation of local government in the form of monitoring, knowledge of monitoring mechanisms, use of media / forums to monitor, and freedom to monitor the implementation of local government. Community participation in local governance has an index of 63.44 which means that the community participation is good.

The third dimension is transparency. Transparency is the disclosure of information in policy-making related to government implementation that can be accessed by the public through various media. Table 2 shows that the local government transparency index of Sidoarjo is 65.52. Transparency indicators can be seen from the availability of public information and mechanisms to obtain them. Public information includes local government policies, the preparation and use of funds, the use of public facilities, public services, and the accessibility of information in an easy, affordable, free, and exact time. The availability of mechanisms is the community's knowledge of mechanisms for obtaining information on the local governments, informed institutions, and media that can be used to access public information.

Accountability, as the fourth dimension, is the accountability of local governments to the public in governance. Accountability is in the form of performance and budget management. The performance of local government can be observed from several indicators that are the suitability between programs and activities prepared with the needs of local communities, synergy with national development programs, shows the expected levels of performance, and programs and activities can be perceived benefits by the community. Budget accountability is the suitability of the budget allocated to the benefits received by the public, compliance with the budget allocation priority needs of local development, the ability to reduce the level of leakage of budget management, as well as monitoring the effectiveness of budget management. Accountability of local government of Sidoarjo has index of 66.03 .

Responsiveness is the sensitivity of local governments in responding to community needs and complaints related to services provided by the government. The suitability between programs and activities that are available with the aspirations and needs of the community is one aspect that should be responded by the local government. 
TABLE 2. MEASUREMENT Result of GoOd GOVERnANCE INDEX IN SidOARJO 2016

\begin{tabular}{|c|l|c|}
\hline No & \multicolumn{1}{|c|}{ Good Governance } & Indeks per Principle \\
\hline 1. & Rule of Law & 66,83 \\
\hline 2. & Participation & 63,44 \\
\hline 3. & Transparency & 65,52 \\
\hline 4. & Accountability & 66,03 \\
\hline 5. & Responsiveness & 62,91 \\
\hline 6. & Equality & 66,14 \\
\hline 7. & Effectiveness and Efficiency & 65,73 \\
\hline 8. & Strategic Vision & 66,20 \\
\hline Good Governance Index & 65,35 \\
\hline Category & Good \\
\hline
\end{tabular}

Source: Primary Data

That sensitivity is assessed by the availability and clarity of mechanisms along with complaints procedures, the intensity of public complaints, and the availability of media to deliver the complaints. The next assessment of responsiveness is the speed and accuracy of the government in handling, resolving and following up on community complaints, as well as the readiness of human resources, infrastructure, and budget. The local government responsiveness index as listed in Table 2 are the lowest that is 62.91 .

Equality is that every citizen has equal opportunity in obtaining services and guarantees from the government fairly and proportionately. That equality can be assessed from the availability of everyone's guarantees for quality services, protection and empowerment. The quality of equality in services provided by the local government to the community is $\operatorname{good}(66.14)$.

The seventh principle is effectiveness and efficiency. Effectiveness is the achievement of a predetermined target. Effectiveness can be assessed from the ability of local government in coordinating programs and development activities among local government officials (SKPD), exploring potential sources of local revenue, improving the quality of public service, social welfare and local competitiveness, as well as the results and benefits of development programs. While efficiency is the accuracy of efforts made in utilizing existing resources such as time, funds, and energy. Efficiency can also be assessed from the ability of local governments to prevent local income and expenditure budget (APBD) deficits and integrated services and one roof. Effectiveness and efficiency in local government has the index of 65.73 .

The description of strategic vision of Sidoarjo government is shown by Table 2 with the score of 66,20. Strategic vision assessment is seen from the clarity of local development plan goals and policy consistency to realize the vision-mission. The clarity of local government development plan goals can be seen from the clarity of vision regarding the development strategic values, the relevance of vision with its potential and the vision of national development, and as well as the easiness to realize the vision of local development. The policy consistency in realizing the vision and mission can be seen from the synergy between the vision and the mission, efforts that have been done, as well as local development programs and activities with development policy.

\section{CONCLUSION}

The conclusions of this research are first, the implementation of good governance consists of eight dimensions. Those eight dimensions are rule of law, participation, transparency, accountability, responsiveness, equality, effectiveness and efficiency, and strategic vision. Second, each principle of good governance in Sidoarjo is categorized as good and has score index above 60. Overall, the good governance index in Sidoarjo is categorized as good and has score index 65.35. The index is better than national good governance index in Indonesia (5.70) and East Java (6.43) on a scale of 10 .

\section{ACKNOWLEDGMENT}

We are thankful to our colleagues in Faculty of Social and Political Sciences Universitas Muhammadiyah Sidoarjo who provided expertise that greatly assisted the research, although they may not agree with all of the interpretations provided in this paper.

\section{REFERENCES}

[1] The Partnership for Governance Reform, "Towards a wellinformed society and responsive government" Executive Report Indonesia Governance Index 2012, The Australian Agency for International Development (AusAID), Jakarta Selatan: Kemitraan bagi Pembaruan Tata Pemerintahan (The Partnership for Governance Reform), 2013.

[2] P. Wolfowitz, "Coordinating for good governance, development committee, annual meeting 2006", http://openknowladge.worldbank.org, download: 22 Agustus 2017.

[3] G. Bouckaert and V.W. Steven, "Comparing measure of citizen trust and user satisfaction as indikators of good governance: dificulties in linking trust and satisfaction indicators," International Review of Administrative Sciences, Journals.Sage.com, 2003, p.329-343.

[4] J. Huther and S. Anwar, "Applying a simple measure of good governance to the debate on fiscal decentralization", Policy Research Working Paper, The World Bank, Operational Evaluation Developmet, 1998.

[5] T.W. Abadi, P. Nunung, and G. Budi, "Capacity and bureaucratic culture in accessibility of public information based on egovernment in Sidoarjo-Indonesia," International Journal of Humanities and Social Science, Vol. 5, No. 6(1), p. 98, June 2015.

[6] A. Dwiyanto, "Mewujudkan good governance melalui pelayanan publik," Yogyakarta: Gadjah Mada Universiti Press, 2006.

[7] J. Widodo, "Good governance telaah dari dimensi akuntabilitas dan kontrol birokrasi," Surabaya: Insan Cendekia, 2012.

[8] P. L. Sinambela, "Reformasi pelayanan publik," Jakarta: Bumi Aksara, 2013.

[9] Y.T. Keban, "Good governance dan capacity building sebagai indikator utama dan fokus penilaian kinerja pemerintahan," Naskah, No. 20, Juni-Juli 2000, Bappenas.

[10] PKP2A I-LAN, "Model pengukuran pelaksanaan good governance di pemerintah daerah Kabupaten/Kota, Bandung: Pusat Kajian dan Pendidikan dan Pelatihan Aparatur I LAN, 2008.

[11] World Bank \& DFID. (2009). "Good governance in public-private partnership." in: http://openknowladge.worldbank.org. download: 22 Agustus 2017. 